\title{
Do native white-clawed crayfish impact macroinvertebrate assemblages in Mediterranean limestone headwaters?
}

\author{
Juan A. Arce ${ }^{1, *}$, Fernando Alonso ${ }^{2}$, Antonio Camacho ${ }^{3}$ and Eugenio Rico ${ }^{4}$ \\ ${ }^{1}$ Agricultural Research Centre of Albaladejito, Agricultural Research Department of the Castile-La Mancha Regional Ministry of \\ Agriculture, Toledo - Cuenca Rd, Km 174, 16194 Cuenca, Spain \\ 2 Department of Forestry and Natural Areas, Agricultural Research Department of the Castile-La Mancha Regional Ministry of \\ Agriculture, Colón St, 2, 16071 Cuenca, Spain \\ ${ }^{3}$ Cavanilles Institute of Biodiversity and Evolutionary Biology, Department of Microbiology and Ecology, University of Valencia, \\ 46100 Burjassot, Valencia, Spain \\ ${ }^{4}$ Department of Ecology, Autonomous University of Madrid, 28049 Madrid, Spain
}

Received: 23 March 2019 / Accepted: 3 June 2019

\begin{abstract}
Crayfish are among the largest aquatic macroinvertebrates in rivers and streams. Their trophic ecology is important for the understanding of the functioning of benthic communities. This is relevant in key areas, such as headwaters, as they partly condition the processes occurring downstream. To shed light on the effects of native white-clawed crayfish, Austropotamobius pallipes, on local macroinvertebrate assemblages from running headwaters, a three-month mesocosm-based field study was designed. Collection and subsequent analysis of benthic samples under different crayfish density levels yielded a set of metrics indicative of short-term impacts at general and taxonomic scales. Neither significant positive nor negative effects on the community were evident in terms of richness, diversity, dominance and biomass. A combination of highly patched distributions of macroinvertebrates along with a weak impact of crayfish foraging activity is considered to explain this lack of effects. Only temporal changes associated with particular biological cycles appeared for some of the main taxa. Based on the results, we are not able to determine whether the white-clawed crayfish perceptibly disturbs the structure and composition of the local macroinvertebrate assemblages in the short-term. Thus, its use in future restocking projects is supported.
\end{abstract}

Keywords: Austropotamobius pallipes / freshwater crayfish / benthic macroinvertebrate / mesocosm / headwater

Résumé - Les écrevisses à pattes blanches indigènes ont-elles un impact sur les communautés de macroinvertébrés dans les eaux d'amont calcaires méditerranéennes? Les écrevisses sont parmi les plus gros macroinvertébrés aquatiques dans les rivières et les ruisseaux. Leur écologie trophique est importante pour la compréhension du fonctionnement des communautés benthiques. C'est pertinent dans des domaines clés, tels que les eaux d'amont, car elles conditionnent en partie les processus qui se produisent en aval. Pour faire la lumière sur les effets de l'écrevisse à pieds blancs, Austropotamobius pallipes, sur les assemblages de macroinvertébrés locaux des eaux d'amont, une étude de trois mois en mésocosme sur le terrain a été conçue. Collecte et analyse d'échantillons benthiques selon les niveaux de densité différentes en écrevisses ont donné un ensemble de paramètres indicatifs des impacts à court terme à l'échelle générale et taxonomique. Aucun effet positif ou négatif important sur la communauté n'était évident en termes de richesse, de diversité, de dominance et de biomasse. On considère que cette absence d'effets s'explique par la combinaison d'une distribution de macroinvertébrés très hétérogène et d'un faible impact de l'activité de recherche de nourriture des écrevisses. Seuls des changements temporels associés à des cycles biologiques particuliers sont apparus pour certains des principaux taxons. D'après les résultats, nous ne sommes pas en mesure de déterminer si l'écrevisse à pattes blanches perturbe à court terme de façon perceptible la structure et la composition des assemblages locaux de macroinvertébrés. Ainsi, son utilisation dans les futurs projets de repeuplement est confortée.

Mots clés : Austropotamobius pallipes / écrevisse / macroinvertébré benthique / mésocosme / rivière de montagne

\footnotetext{
*Corresponding author: cangrejus2010@gmail.com
} 


\section{Introduction}

Headwaters are essential areas in catchment basins. Their small size allows contact between the aquatic and terrestrial compartments, therefore increasing their connectivity. Furthermore, headwaters are critical for organic matter processing, nutrient recycling and biodiversity (Wallace et al., 1997; Peterson et al., 2001). Considering rivers as ecological units that change from their origin to the river mouth, headwater communities do partially determine ecological processes and dynamics downstream (Vannote et al., 1980; Cole et al., 2003). Among the main organisms living in these habitats are benthic macroinvertebrates. They include juvenile and/or adult stages of many insects, as well as crustaceans, mites and other nonarthropod taxa. Most of them dwell on the streambed, with an important role in energy transmission between primary producers and secondary consumers (Rodrígues-Capítulo et al., 2009). In relation to other aquatic organisms, macroinvertebrates are relatively sedentary, and have medium-tolong life cycles. They also show particular affinities for different microhabitats, and variations in their communities can appear on the small habitat scale (Burgazzi et al., 2018). These features have enhanced their use as spatial and temporal bioindicators for water pollution and other human impacts on riverine ecosystems over the last several decades (Woodiwiss, 1978; Friedrich et al., 1992; Camargo, 2019). Amongst the largest benthic macroinvertebrates living in continental waters are crayfish (Decapoda, Astacidea) (Alonso et al., 2000), which are considered omnivorous organisms. Plants, algae, water mosses, invertebrates and detritus are considered as their main dietary resources (Brown et al., 1990; Usio and Townsend, 2002; Rodríguez et al., 2005; Holdich et al., 2006; Haddaway et al., 2012; Reynolds et al., 2013). Many studies involving preference trials in aquaria, analysis of gut contents from wild populations or stable isotope techniques support this idea (Warner, 1995; Whitledge and Rabeni, 1997; Olsson et al., 2008; Rosewarne et al., 2016). However, within the context of omnivory, crayfish should attempt to optimize the cost-benefit relationship. Therefore, a shift in their diet toward macroinvertebrates over other sources may be expected (Hill et al., 1993; Ilhéu and Bernardo, 1993). Macroinvertebrates have a higher protein content, digestibility and assimilation rate than typical of macrophytes and algae. These, in turn, are richer in plant fibre and antinutritional compounds (Brown et al., 1990; Momot, 1995). In situations in which crayfish take on a predatory role, their position within the trophic network may be modified (Nyström, 2002; Olsson et al., 2008). To shed light on this topic, many studies in recent decades have focused on the effects of crayfish on specific groups of macroinvertebrates, either through field surveys or aquaria trials (Perry et al., 1997; Warner, 1997; Holdich et al., 2006; Taylor and Dunn, 2018). In such cases, crayfish were considered keystone species due to their ability to modulate the energy flows in freshwater ecosystems (Matthews et al., 1993; Davic, 2003; Hansen et al., 2013; Rosewarne et al., 2016). According to Geiger et al. (2005), crayfish should be considered ecological turbator agents for those habitats where local communities are markedly disturbed by them. The whiteclawed crayfish, Austropotamobius pallipes (Lereboullet, 1858) species complex, is the only crayfish native to the
Iberian Peninsula (Alonso, 2011). Although there is some controversy on the scientific name of this species, up to date no definitive consensus has been reached. For this reason we decided to be conservative and keep the original and traditionally accepted denomination of $A$. pallipes s.l. through the whole manuscript. A summary of this topic is exposed by Chiesa et al. (2011). More abundant in the past, their populations have been decimated in recent decades by humanmediated actions. Habitat degradation and disease transmission by two invasive species, the red-swamp crayfish (Procambarus clarkii Girard, 1852) and the signal crayfish (Pacifastacus leniusculus Dana, 1852), have been the main cause of their decline (Diéguez-Uribeondo, 2006; Füreder, 2006). Other threats have also been specially patent in northern Spain, where the presence of native crayfish in heavily forested areas results in a conflict of interests and makes its conservation particularly difficult (García-Arberas et al., 2010). Among current wild A. pallipes Iberian populations, those in central Spain are restricted to marginal sites where pressures are absent in practice. These sites mostly align with isolated stretches within limestone headwaters (Alonso et al., 2000; Arce and Alonso, 2011). To our knowledge, studies on trophic interactions between $A$. pallipes and the coexisting benthic biota are absent for Iberian water courses. Available information on this issue relates to the exotic $P$. clarkii (Ilhéu and Bernardo, 1995; Geiger et al., 2005; Rodríguez et al., 2005). The present work aimed to partially fill this gap by assessing the impacts of white-clawed crayfish on macroinvertebrate communities living in cold Mediterranean limestone headwaters. We seek to gain insight into the effects of the white-clawed crayfish on whole assemblage descriptors such as richness, abundance, diversity and biomass. We expect a reduction in value for all of them except for the community dominance. Single impacts at a taxonomic scale were monitored for most representative groups, in an attempt to obtain useful data to explain the tendencies shown by the general descriptors. Based on these results, the community role of white-clawed crayfish as a short-term modulator species is discussed.

\section{Materials and methods}

\subsection{Study area}

The study was carried out in a Mediterranean mountain area in central Spain (Fig. 1), within the boundaries of Serranía de Cuenca Natural Park. Mean annual air temperature and rainfall are about $10{ }^{\circ} \mathrm{C}$ and $1000 \mathrm{~mm}$, respectively. A predominance of steep limestone ridges between 900 and $1850 \mathrm{~m}$ a.s.l. favours the presence of a dense hydrographic network. This consists of rivers, brooks, creeks, springs, caves and other karstic landforms. The field work was carried entirely in the upper part of Arroyo del Rincón, an undisturbed tributary stream flowing into the Júcar River. No natural populations of crayfish dwelled into this stream. Although some of the flow is diverted to a trout hatchery, most of the water volume flows through the natural stream channel where the trials were conducted. A rectangular $80 \mathrm{~m}$ stretch was selected to perform the trials, with public access prevented by the hatchery's fence (Fig. 1); in this way, any possibility of damage, destruction or stealing of the experimental equipment, 


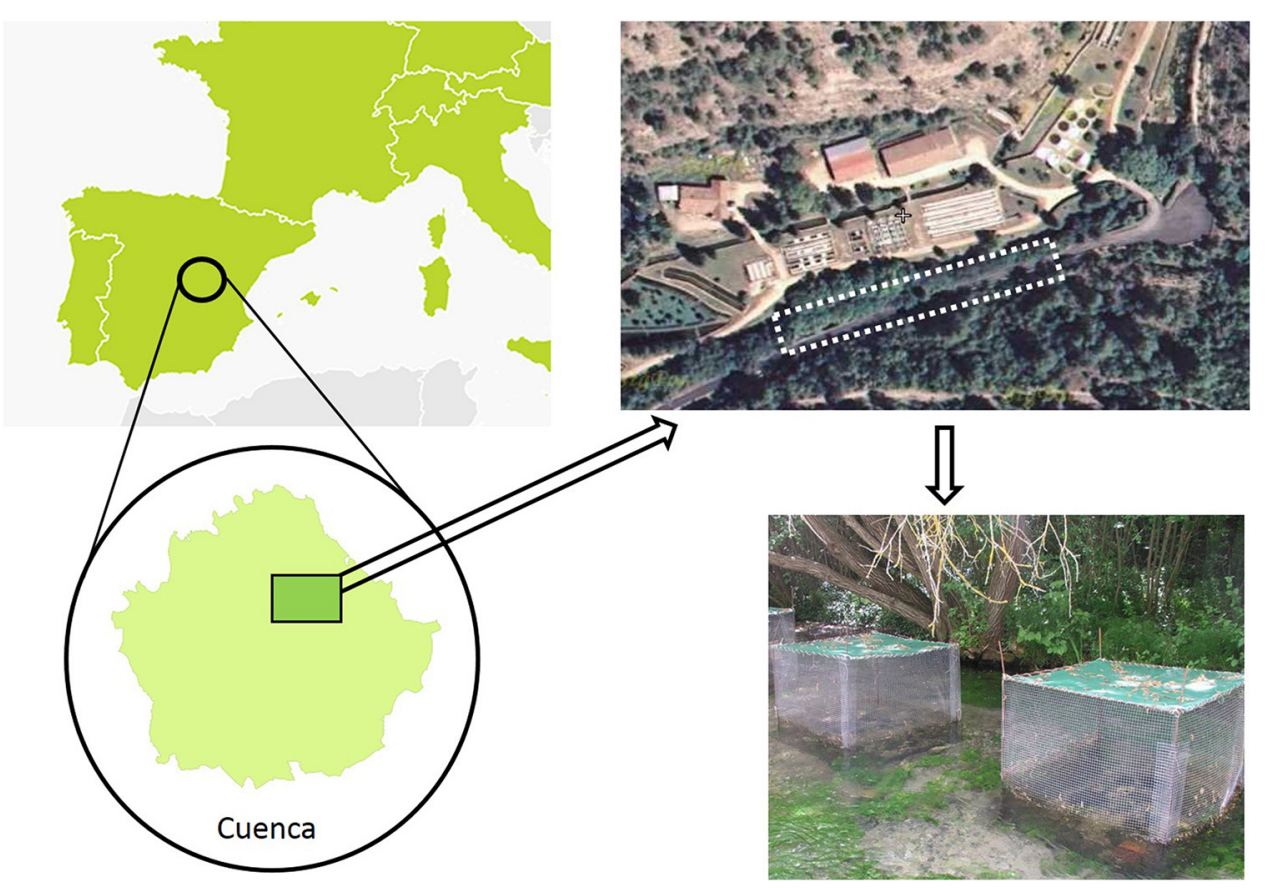

Fig. 1. Location of the study area showing the selected $80-\mathrm{m}$ stretch (dotted line), and design of mesocosms along on the streambed for trials at Arroyo del Rincón.

as well as poaching or the transmission of crayfish plague (Aphanomyces astaci Schikora, 1906), was minimized. Riparian vegetation was integrated with a mixed assemblage of willows and hazelnuts, which projected a patched shadow onto the water surface. The mesohabitat was a succession of shallow runs $(<0.5 \mathrm{~m})$ locally interrupted by small riffles, lacking pools or alternative fine sediment depositions. The streambed consisted of a $15-20 \mathrm{~cm}$ deep layer of a mixture of pebbles, cobbles and coarse gravel. Basic physical and chemical parameters were regularly measured during the trials through portable probes, including $\mathrm{pH}$ (Metro Thermo ORION $210 \mathrm{~A}+$ ), conductivity (ORION ATI 130 with coupled thermometer) and dissolved oxygen (Microprocessor OXI 96). Average values of temperature $\left(10.18 \pm 0.34^{\circ} \mathrm{C}\right)$, disolved oxygen $\left(9.02 \pm 0.20 \mathrm{mg} \mathrm{L}^{-1}\right), \mathrm{pH}(7.32 \pm 0.22)$ and specific conductance $\left(479.7 \pm 3.78 \mu \mathrm{S} \mathrm{cm}^{-1}\right)$ are typical of limestone freshwaters, and were within the tolerance range observed for A. pallipes (Füreder, 2006; Holdich et al., 2006; Arce and Alonso, 2011).

\subsection{Experimental design}

We performed an assessment based on outdoor mesocosms under semi-controlled conditions. This allowed us to manipulate crayfish density as a pressure measure on the ecosystem. With this aim, several enclosures were installed on the selected stretch. Each enclosure consisted of a cubic cage with a bottom surface area of $1 \mathrm{~m}^{2}$ and covered by a $13-\mathrm{mm}$ mesh wire. This size allowed the free movement of macrobenthic invertebrates while preventing adult crayfish from escaping.

Twelve enclosures were distributed along the streambed and assigned to one of three treatments: zero (controls), one or two crayfish. Control mesocosms simulated the natural condition of the stream, whereas one- and two-crayfish treatments reflected natural densities of $A$. pallipes found in Western Europe streams (Benvenuto et al., 2008; Wendler et al., 2015). According to Alonso (2004), those values are also equivalent to crayfish biomass usual for populations in the surrounding area of our trials. Four randomly allocated replicates for each treatment were employed. To avoid the removal of individuals from wild crayfish populations, given their endangered status, the experimental specimens were obtained from a nearby crayfish hatchery. Only healthy adult males of similar sizes (carapace length $=44.8 \pm 1.61 \mathrm{~mm}$, body weight $=30.38 \pm 3.72 \mathrm{~g}$ ) were selected to avoid any bias influenced by sex or size. The biomass of individuals used in the one- and two-crayfish trials was around 30 and $60 \mathrm{~g} \mathrm{~m}^{-2}$, respectively. These are typical values for populations in the surrounding area (Alonso, 2004). The crayfish were previously acclimatized in nearby cages in the stream for three weeks. An extra stock was available in case experimental crayfish needed to be replaced during the trials. At the conclusion of the trials, test individuals were collected and brought to laboratory for ethological assays non-related with the present study.

\subsection{Field sampling and laboratory analyses}

A three-month study was performed from mid-spring to mid-summer of 2013. Quantitative samples of benthic macroinvertebrates were collected from each mesocosm every two weeks, for a total of six sampling campaigns. Samples were collected by manually scraping the bottom substrate included in a $0.1-\mathrm{m}^{2}$ frame Surber net. Occasionally, medical pincers were needed to sample sessile macroinvertebrates grouped together in stone cavities, primarily aquatic snails and 


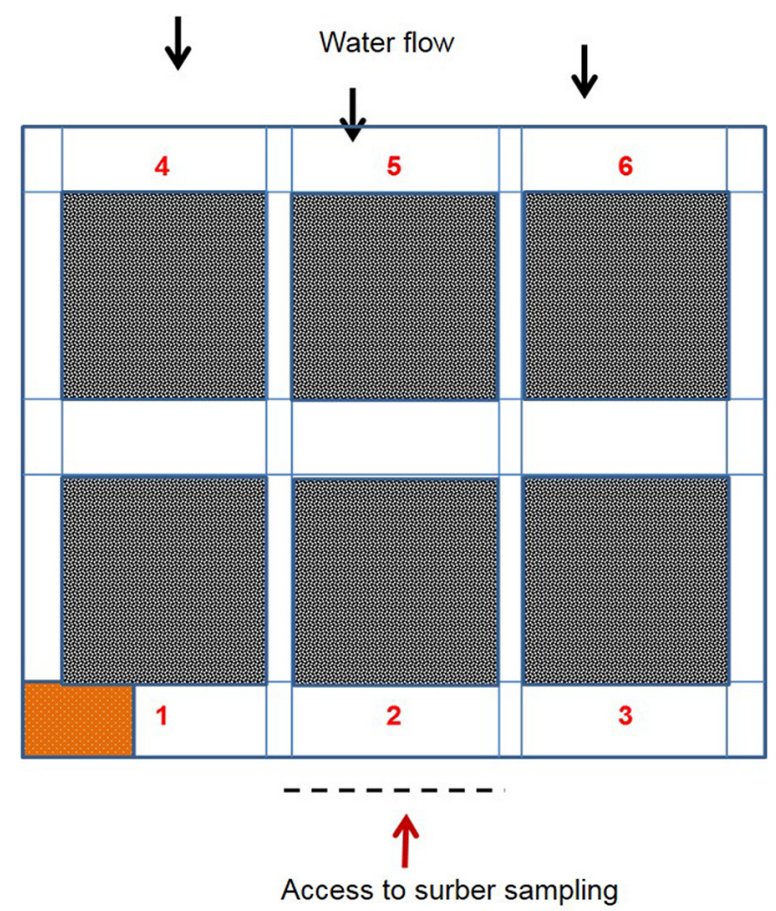

Fig. 2. Top view of a $1 \mathrm{~m}^{2}$ enclosure used for the mesocosm field study, where distribution of the patches to be quantitatively sampled is depicted. Predetermined collection order of samples is defined with numbers. A brick used as a shelter for crayfish is also shown in the left corner.

cased caddisfly larvae. As this method entailed the removal of benthic assemblages, we did not sample the same patch within a mesocosm for the subsequent campaigns in order to avoid unrepresentative data. For that reason, at the beginning of the trials, the entire surface of each cage was visually divided into six similar $0.1-\mathrm{m}^{2}$ patches. Each one was surveyed only once during the experiment. To maintain the same sampling sequence for all the mesocosmos, the six patches were surveyed in the same order, as depicted in Figure 2. Crayfish survival was checked twice a week.

Macroinvertebrate samples were washed in situ through a 1-cm mesh-size sieve to remove the largest elements, such as gravel, leaves, twigs, sticks and small branches. They were immediately preserved in wide-mouth plastic jars with $4 \%$ formaldehyde and brought to the laboratory. Then samples were washed again over two superimposed sieves of $1-\mathrm{cm}$ and $300-\mu \mathrm{m}$ mesh-size. The larger fraction was directly assessed on a tray, while the smaller one was examined under a stereoscope. Macroinvertebrates were sorted and identified to family, genus or species levels, but 'family' was the taxonomic group used in subsequent analyses. The exceptions were Oligochaeta (worms) and Acari (Hydracarina, water mites), which were analysed at the class and order level, respectively. Afterwards, macroinvertebrates were counted and classified separately for further desiccation in an oven at $60^{\circ} \mathrm{C}$ for $24 \mathrm{~h}$. Taxa dry mass was obtained by means of a precision weighing scale $( \pm 0.1 \mathrm{mg})$. In order to provide community-level comparisons between treatments and sampling times, we calculated a set of metrics. These included parameters like richness, diversity, abundance and biomass for all or particular taxa. All the metrics referred to a single sample obtained from each patch, although abundance and biomass data were later related to a square meter surface (Tab. 1). Taxonomic richness is considered a good indicator for the biological community structure, even when defined at the family level (Resh and Jackson, 1993). We also obtained EPT richness - which accounted for the individual addition of Ephemeroptera, Plecoptera and Trichoptera richness - due to the relevance of these three groups as water quality indicators in freshwater ecosystems (Williams and Feltmate, 1992; Camargo, 2019). Diversity was calculated with Margalef's Index (D), because of its simplicity and ease of use.

\subsection{Data analysis}

Variations in the metrics described above were compared by applying a mixed ANOVA general linear model (GLM), also known as a split plot model. Two fixed factors were considered: the number of crayfish per mesocosm (none, one or two) as a treatment or between-subject factor, and the sampling time $(14,28,42,56,70$ and 84 days) as a repeated measures within-subject factor. To achieve the specific assumptions required by this kind of parametric analysis, we performed normality tests for every level combination of both factors (crayfish density $\times$ sampling time). We choose the Shapiro-Wilk test $(\alpha$-level $=0.05)$ due to its suitability for samples of less than 50 cases. Data that did not match a normal distribution for a particular crayfish treatment or sampling time were square-root or log-transformed, depending on the relationship between the mean and the variance (Elliot, 1977; Sokal and Rohlf, 1995). For total abundance and biomass of macroinvertebrates, the $\log (\mathrm{x})$ transformation was used. Those referring to particular taxa were $\log (x+1)$ converted, given that the appearance of zero cases among datasets is common in these types of experimental designs (Sokal and Rohlf, 1995; Mathews, 2010). Dominance, expressed as the percentage represented by the most abundant taxa in a sample (Tab. 1), was transformed through the arcsine function. Those variables whose ditributions remained nonnormal despite the transformations applied were still assessed; this is due to the absence of non-parametric alternative proofs for these types of tests and the robustness of ANOVA tests in balanced designs (Sokal and Rohlf, 1995). A significance threshold of 0.05 for $\alpha$-level was set, with $\eta^{2}$ values indicating the magnitude of any particular effect. Bonferroni correction was employed to adjust confidence intervals prior to analysis of interactions between treatments. Homogeneity of variances for each sampling time was checked through the homoscedasticity Levene's test ( $p>0.05$, assumed homocedasticity). Similarly, the homogeneity of variances of the differences between the data obtained at several sampling times was pairwise-verified with the Mauchly's test of sphericity ( $p>0.05$, assumed sphericity). Post hoc tests were run for each dependent variable. When data matched homocedasticity, Gabriel's pairwise comparisons were applied; in other cases, Games-Howell's nonparametric test was used. Finally, when the sphericity hypothesis on the effects of sampling time and its interaction with crayfish density was rejected, values generated by the Huynh-Feldt correction $(\varepsilon)$ were automatically accepted, since it is the alternative tool which adjusts the 
Table. 1. List of metrics calculated from values of taxonomic richness, diversity, abundance and biomass of benthic macroinvertebrate samples collected in Arroyo del Rincón.

\begin{tabular}{ll}
\hline Metrics & Definition \\
\hline Total taxonomic richness & Total number of families + Oligochaeta + Hydracarina \\
EPT richness & Total number of families belonging to Ephemeroptera (mayflies), Plecoptera (stoneflies) and \\
& Trichoptera (caddishflies) \\
Total abundance & Total abundance $\left(\right.$ ind $\mathrm{m}^{-2}$ ) of macroinvertebrates \\
Abundance by families & Abundance $\left(\mathrm{ind}^{-2}\right)$ of macroinvertebrates grouped by families \\
Dominance & Percent of the most abundant taxon in relation to the total number of macroinvertebrates \\
& for each sample \\
Total biomass & Total dry mass $\left(\mathrm{mg} \mathrm{m}^{-2}\right)$ of macroinvertebrates \\
Biomass by families & Dry mass $\left(\mathrm{mg} \mathrm{m}^{-2}\right)$ of macroinvertebrates grouped by families \\
Margalef's diversity index & $D=($ Total taxonomic richness -1$) / l n$ (Total abundance) \\
\hline
\end{tabular}

degrees of freedom of models lacking data sphericity. At a taxonomic level, analyses were performed for the most important macroinvertebrate groups within the assemblage. In this sense, only those taxa accounting for at least $2 \%$ of total abundance and/or biomass in a sample for the whole experiment were selected. The calculation of metrics and variable transformations were performed with Microsoft ${ }^{\circledR}$ Excel 2010. Statistical analyses were carried out with the SPSS $^{\circledR}$ Statistics package version 22.

\section{Results}

\subsection{Taxonomic richness, diversity and dominance of macroinvertebrates}

A total of 36 families of benthic macroinvertebrates, along with representatives of Oligochaeta and Hydracarina, were identified in Arroyo del Rincón. All raw data are found in Appendix A. Sixteen families (42.1\%) belonged to the orders Ephemeroptera, Plecoptera or Trichoptera (EPT taxa). Average taxonomic richness varied during the trials from 16 to 23 families per mesocosm, half of that number ( 8 to 11) belonging to EPT taxa (Figs. 3a and 3b). Total richness was moderately constant over time attending to crayfish density and sampling time separately $(p>0.05)$. However, a slight increase in EPT values was detected with time $\left(F_{5,40}=3.649, p<0.01\right.$, $\left.\eta^{2}=0.313\right)$. In general, both total and EPT richness showed a certain stability and a high paired correlation $\left(r_{\mathrm{P}}=0.798\right.$, $p<0.001 ; n=70)$. Some punctual interactions of crayfish density appeared at certain sampling times for total richness $\left(F_{10,40}=3.135, \quad p<0.01, \quad \eta^{2}=0.439\right) \quad$ and EPT richness $\left(F_{10,40}=3.120, \quad p<0.01, \eta^{2}=0.439\right) \quad$ (Tab. 2). Margalef's diversity index was also fairly constant throughout the trials, scoring average values around 2.0 (Fig. 3f). No interactions were observed between crayfish treatment and sampling time $\left(F_{10,40}=1.845, p>0.05\right)$ (Tab. 2). Up to five different taxa were numerically dominant at any given stage of the experiment: water mites (Hydracarina, 53.3\% of the cases), riffle beetles (Elmidae, 27.1\%), mud snails (Hydrobiidae, 8.6\%), Brachycentridae $(7.1 \%)$ and Limnephilidae $(2.9 \%)$. As depicted in Figure $3 \mathrm{e}$, the average dominance showed moderately similar ranges for the three crayfish treatments: $25.5-39.3 \%$ for controls, $21.1-38.3 \%$ for one-crayfish mesocosms and
28.4-38.1\% for two-crayfish mesocosms. No significant effects appeared for dominance during the experiment $(p>0.05)$. Furthermore, none of the described variables showed changes directly linked to crayfish density $\left(F_{2,8} ; p>0.05\right)$.

\subsection{Total abundance and biomass of macroinvertebrates}

Very different values of total abundance and biomass of macroinvertebrates appeared throughout the study, accounting for $4500-18500 \mathrm{ind}^{-2}$ and $1600-7200 \mathrm{mg} \mathrm{m}^{-2}$, respectively (Figs. $3 \mathrm{c}$ and $3 \mathrm{~d})$. Neither average abundance $\left(F_{5,40}=1.077\right.$, $p>0.05)$ nor biomass $\left(F_{5,40}=1.526, p>0.05\right)$ significantly varied across sampling times for all treatments. Both variables showed higher variances among replicates of the same treatments (crayfish density $\times$ sampling time) compared to different treatments, i.e., intragroup variance was greater than intergroup variance. Only one exceptional interaction between sampling time and crayfish density was observed $\left(F_{10,40}=2.481, p<0.05, \eta^{2}=0.383\right)$ on the final sampling date (Tab. 2), when very high abundances and biomass appeared in the two-crayfish mesocosms (Figs. 3c and 3d). A strongly paired correlation existed between total abundance and biomass of macroinvertebrates $\left(r_{\mathrm{P}}=0.863, p<0.001, n=70\right)$.

\subsection{Particular effects on taxa}

Twelve out of 38 taxa were the main contributors to the macrobenthic assemblage, since they accounted for $93 \%$ of total abundance and $85 \%$ of total biomass (Tab. 3). Caddisflies contributed the most with four families. With respect to abundances, only the main effects of sampling time were significant for some taxa: Hydracarina $\left(F_{5,40}=3.163\right.$, $\left.p<0.05, \quad \eta^{2}=0.283\right), \quad$ Polycentropodidae $\quad\left(F_{5,40}=2.888\right.$, $\left.p<0.05, \eta^{2}=0.265\right)$, Limnephilidae $\left(F_{5,40}=4.213, p<0.01\right.$, $\left.\eta^{2}=0.345\right)$, Leuctridae $\left(F_{5,40}=21.11, p<0.001, \eta^{2}=0.725\right)$ and Chironomidae $\left(F_{5,40}=13.09, \quad p<0.001, \quad \eta^{2}=0.621\right)$ (Tab. 3).

A progressive decrease in abundance of Leuctridae was evident for all crayfish density treatments $(72.5 \%$ variance explained) along the experiment (Fig. 4). On the contrary, Limnephilidae showed increasing numbers from the beginning 

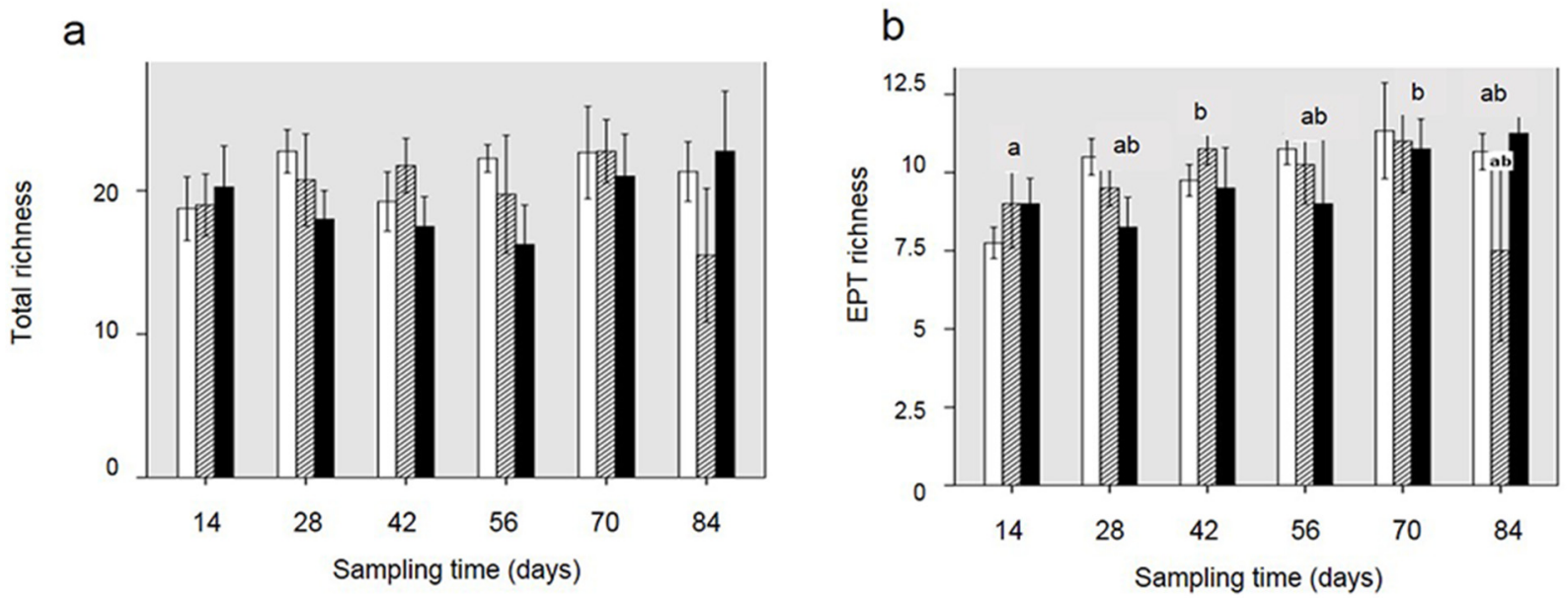

C

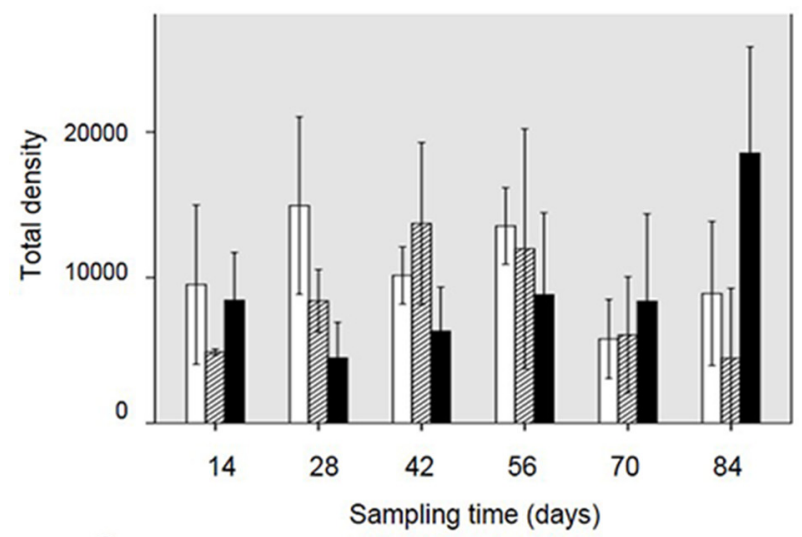

e
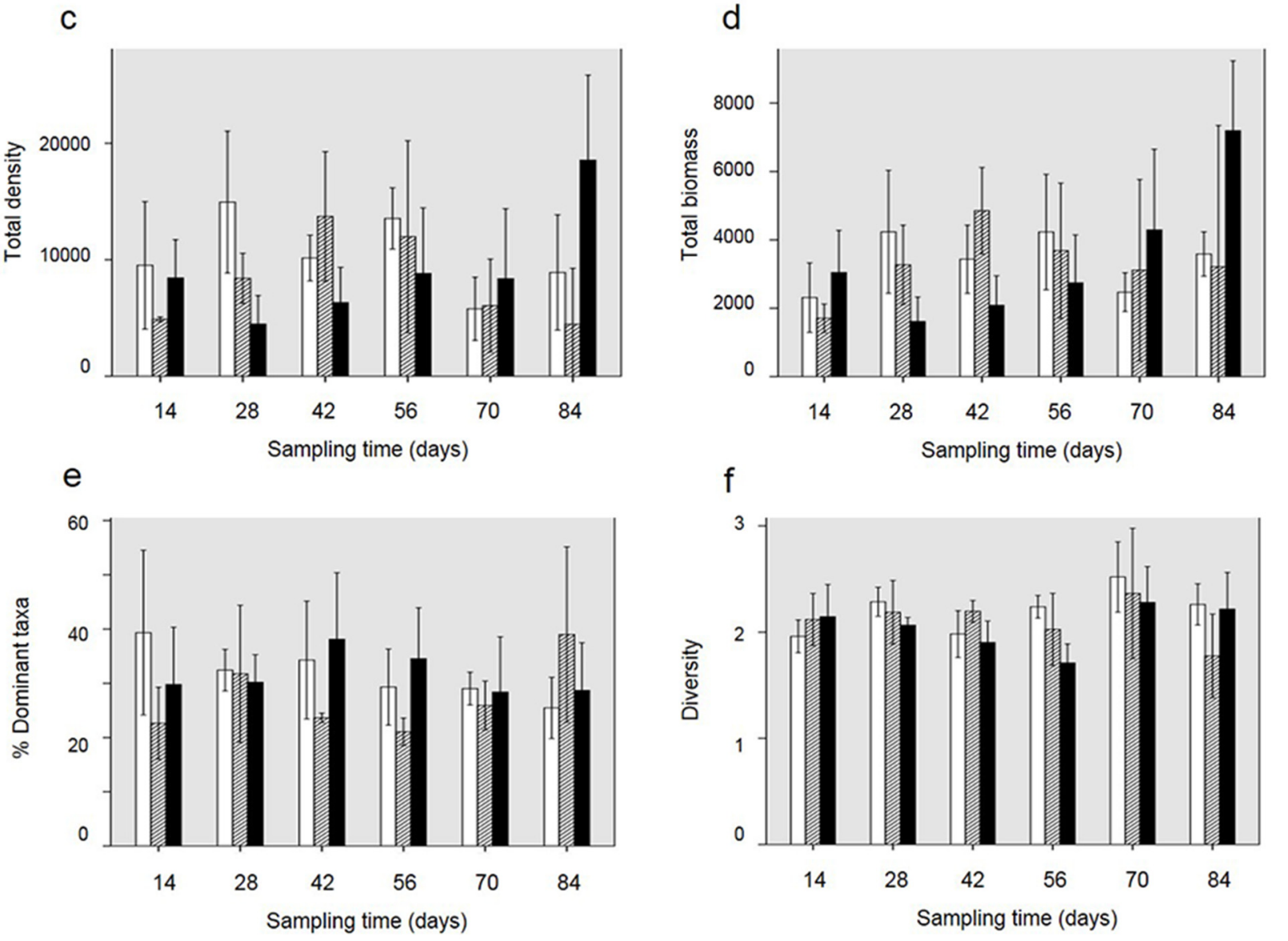

Fig. 3. Temporal variation (mean $\pm 1 \mathrm{SD}$ ) of macroinvertebrates in (a) total taxonomic richness (number of families), (b) EPT richness (number of EPT families), (c) total density (ind $\mathrm{m}^{-2}$ ), (d) total biomass $\left(\mathrm{mg} \mathrm{m}^{-2}\right)$, (e) dominance (ind. dominant taxon/ind. total taxa) and (f) diversity (Margalef's index) sampled in the control (white), one-crayfish (grey) and two-crayfish (black) enclosures. For Graph b, crayfish density treatments that significantly differed from each other are denoted with different lowercase letters over the bars ( $a, b)$, and combinations of these letters $(\mathrm{ab})$ indicate a lack of effects in relation to individual groups.

of the experiment. Chironomid abundance experienced a gradual increase during the first two months but, from this point on, values suffered a sudden decline. Finally, the effects on Hydracarina were unclear, given the erratic fluctuation of abundances and the low explained variance (28.3\%). It was notable that all the described taxa showed a wide intragroup variance within the same treatments (Fig. 4).
With regard to biomass of macroinvertebrates, an effect of sampling time appeared in the case of Elmidae $\left(F_{5,40}=3.223\right.$, $\left.p<0.05, \quad \eta^{2}=0.287\right), \quad$ Leuctridae $\left(F_{5,40}=13.970, \quad p<0.001\right.$, $\left.\eta^{2}=0.636\right), \quad$ Brachycentridae $\quad\left(F_{5,40}=7.067, \quad p<0.001\right.$, $\left.\eta^{2}=0.469\right)$ and Chironomidae $\left(F_{5,40}=4.778, \quad p<0.01\right.$, $\eta^{2}=0.374$ ) (Tab. 3). Biomass of Elmidae and Brachycentridae increased along the experiment (Figs. 5a and 5c). On the other 
Table 2. Total effects for the variables monitored in the mesocosm-based field study in relation to sampling time, crayfish density and their interactions.

\begin{tabular}{|c|c|c|c|c|c|c|}
\hline \multirow[t]{2}{*}{ Variable } & \multicolumn{2}{|c|}{ Sampling time } & \multicolumn{2}{|c|}{ Crayfish density } & \multicolumn{2}{|c|}{$\mathrm{ST} \times \mathrm{CD}$} \\
\hline & $p$ & $\eta^{2}$ & $p$ & $\eta^{2}$ & $p$ & $\eta^{2}$ \\
\hline Total richness & NS & & NS & & $* *$ & 0.439 \\
\hline EPT richness & $* *$ & 0.313 & NS & & $* *$ & 0.438 \\
\hline Total abundance & NS & & NS & & $*$ & 0.383 \\
\hline Total biomass & NS & & NS & & $*$ & 0.404 \\
\hline Dominance & NS & & NS & & NS & \\
\hline Margalef's diversity index & $*$ & 0.267 & NS & & NS & \\
\hline
\end{tabular}

Significant results are highlighted with $*(p<0.05)$ or $* *(p<0.01)$, and corresponding magnitude of effect $\left(\eta^{2}\right)$ expressed. NS $=$ Non-significant results.

Table 3. Particular effects on abundance (left half) and biomass (right half) of the most important macroinvertebrate taxa according to sampling time (ST), crayfish density (CD) and their interactions in the present study.

\begin{tabular}{|c|c|c|c|c|c|c|c|c|c|c|c|c|}
\hline \multirow[t]{3}{*}{ Taxa } & \multicolumn{6}{|c|}{$\log _{10}\left(\right.$ ind $\left.m^{-2}+1\right)$} & \multicolumn{6}{|c|}{$\log _{10}\left(\mathrm{mg} \mathrm{m}^{-2}+1\right)$} \\
\hline & \multicolumn{2}{|c|}{ ST } & \multicolumn{2}{|c|}{$\mathrm{CD}$} & \multicolumn{2}{|c|}{$\mathrm{ST} \times \mathrm{CD}$} & \multicolumn{2}{|c|}{ ST } & \multicolumn{2}{|c|}{$\mathrm{CD}$} & \multicolumn{2}{|c|}{$\mathrm{ST} \times \mathrm{CD}$} \\
\hline & $p$ & $\eta^{2}$ & $p$ & $\eta^{2}$ & $p$ & $\eta^{2}$ & $p$ & $\eta^{2}$ & $p$ & $\eta^{2}$ & $p$ & $\eta^{2}$ \\
\hline Planariidae & NS & & NS & & ** & 0.433 & NS & & NS & & NS & \\
\hline Hydrobiidae & NS & & NS & & $*$ & 0.414 & $*$ & 0.291 & NS & & $*$ & 0.387 \\
\hline Gammaridae & NS & & NS & & $*$ & 0.436 & NS & & NS & & NS & \\
\hline Hydracarina & $*$ & 0.283 & $*$ & 0.663 & NS & & NS & & NS & & NS & \\
\hline Baetidae & NS & & NS & & NS & & NS & & NS & & NS & \\
\hline Leuctridae & $* * *$ & 0.725 & NS & & NS & & $* * *$ & 0.636 & NS & & NS & \\
\hline Elmidae & NS & & NS & & NS & & $*$ & 0.287 & NS & & NS & \\
\hline Polycentropodidae & $*$ & 0.265 & NS & & $*$ & 0.360 & NS & & NS & & $* *$ & 0.461 \\
\hline Limnephilidae & $* *$ & 0.345 & NS & & NS & & NS & & NS & & NS & \\
\hline Brachycentridae & NS & & NS & & NS & & $* * *$ & 0.469 & NS & & NS & \\
\hline Sericostomatidae & NS & & NS & & NS & & NS & & NS & & NS & \\
\hline Chironomidae & $* * *$ & 0.621 & NS & & NS & & $* *$ & 0.374 & NS & & NS & \\
\hline
\end{tabular}

Significant results are highlighted with * $(p<0.05), * *(p<0.01)$ or $* * *(p<0.001)$, and the corresponding magnitude of effect $\left(\eta^{2}\right)$ expressed.

hand, biomass of Leuctridae tended to decrease at the end of the experiment similar to abundance, showing a high variance explained by the sampling time $(63.6 \%)$. The same pattern was evident for Chironomidae, although more attenuated (Tab. 3 and Fig. 5d). Interactions between sampling time and crayfish density were exceptional for only two taxa: Polycentropodidae $\left(F_{10,40}=3.425, p<0.01, \eta^{2}=0.461\right)$ and Hydrobiidae $\left(F_{10,40}=2.527, p<0.05, \eta^{2}=0.387\right)$, although no clear tendencies could be defined for the entire experiment (Figs. 5e and 5f). The rest of the monitored families did not show significant effects for biomass $(p>0.05)$ with respect to sampling time and crayfish treatment (Tab. 3).

\section{Discussion}

\subsection{Taxonomic richness, diversity and dominance of macroinvertebrates}

EPT richness contributed, to a large extent, to the total number of families recorded - chiefly due to Trichoptera families - in the well-conserved headwaters of Arroyo del Rincón. This supports the importance of Ephemeroptera, Plecoptera and Trichoptera as water quality indicators in freshwater ecosystems (Williams and Feltmate, 1992; Camargo, 2019). It is interesting that the mean values for total richness and EPT richness obtained for any individual mesocosm at punctual sampling times were lower than total values for the entire trial, independent of crayfish treatments. The main reason lies in the large proportion of rare or uncommon families - around $40 \%$ of the total - which were only present in a small fraction of the samples. It is typical that macroinvertebrate assemblages involving high taxonomic richness also harbour certain infrequent groups, i.e. rare taxa (Rodrígues-Capítulo et al., 2009). However, the likelihood of these rare taxa to be collected during standard sampling is less than for more common species. Indeed, their detection depends on sampling strategy and sampling intensity (Nijboer and Verdonschot, 2004). For EPT families, the sporadic appearance of some of them (i.e., Leptophlebiidae, Ephemerellidae, Perlidae, Hydropsychidae, Ryacophilidae and Hydroptilidae) 

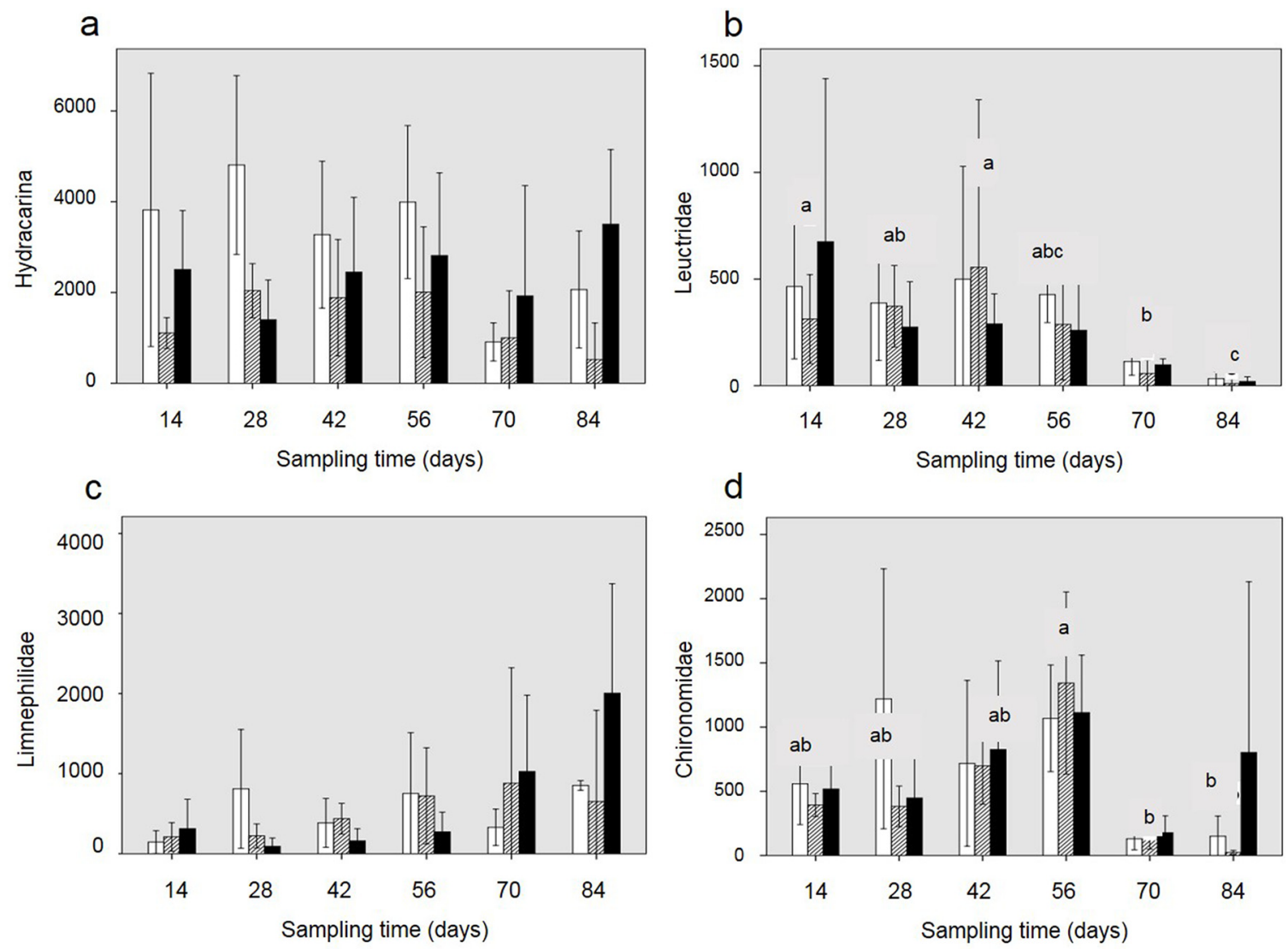

Fig. 4. Temporal variation of abundance (ind $\mathrm{m}^{-2}$, mean $\pm 1 \mathrm{SD}$ ) of macroinvertebrates collected in the control (white), one-crayfish (grey) and two-crayfish (black) enclosures. Only graphs for taxa displaying significant effects are depicted: (a) hydracarina, (b) leuctridae, (c) limnephilidae and (d) chironomidae. Crayfish density treatments that significantly differed from each other are denoted with different lowercase letters over the bars $(a, b, c)$, and combinations of these letters $(a b, a b c)$ indicate a lack of effects in relation to individual groups.

determined punctual, statistically significant changes for this variable among sampling times. Such changes ocurred even when no real variations in total richness had appeared. Although rare taxa accounted for richness estimations, they were excluded from the subsequent assessment of abundance and biomass for particular macroinvertebrate families due to their scarce contribution to potential impacts (Cooper and Barmuta, 1993), as discussed in the Section 2. Despite the fact that dominance values were fluctuating, intergroup differences were always masked by intragroup variance, thus preventing the appearance of significant effects. As a rule, average dominance was always lower than $40 \%$. This meant that the most abundant taxon at every time point was never a strictly monodominant group at the community level (Peh et al., 2011). On the contrary, diversity was quite stable along the experiment, with values slightly over 2.0. This turns out to be a high score for Margalef's index taking into account that, even in pristine running waters or small springs as in our study area, macroinvertebrate diversity can be naturally limited by habitat conditions (Friedrich et al., 1992). In our case, the combination of good diversity and moderate dominance scores conditioned a continuous balanced assemblage, independent of the presence or absence of crayfish in the mesocosms. So, the initial hypothesis that crayfish might be disturbing elements for the whole macroinvertebrate community cannot be confirmed.

\subsection{Total abundance and biomass of macroinvertebrates}

Neither total abundance nor biomass of macroinvertebrates experienced short-term significant changes, regardless the presence of crayfish in the mesocosms. Temporal fluctuations did not follow any consistent pattern. At first glance, this lack of effects was partly conditioned by the wide intragroup variations observed during the entire experiment, which sometimes largely exceeded the differences between factors. This may be related to the patched distributions of the most abundant taxa, which showed variations up to $300 \%$ in numbers among replicates belonging to the same treatments. Such variations in abundance also appeared in biomass estimates because of the strongly paired correlation between them. Patched or contagious distributions are frequent in aquatic macroinvertebrate assemblages, and therefore inherent to the results obtained in the majority of quantitative surveys (Flecker and Allan, 1984; Townsend and Hildrew, 1994). Such distributions appear when stream reaches, which are apparently homogeneous in substrate size, water depth, current velocity, food supply or shelter, actually mask a small-scale mosaic of habitat areas available for aquatic macroinvertebrates. Many taxa tend to concentrate their activity in the form of diversity pockets in those patches, which act as keystone structures (Casas, 1996; Reynolds et al., 2013). Through this 

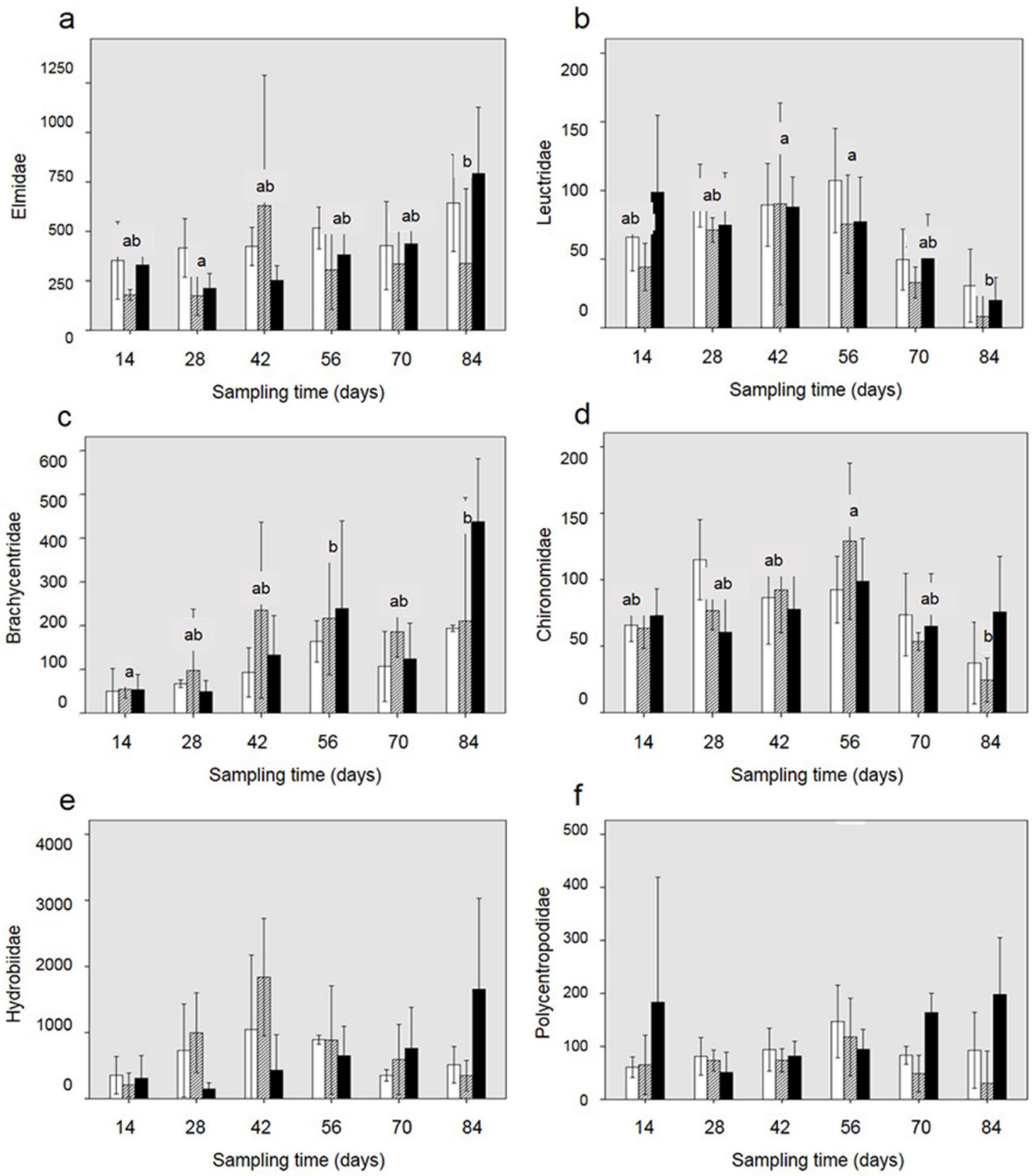

Fig. 5. Temporal variation of biomass $\left(\mathrm{mg} \mathrm{m}^{-2}\right.$, mean $\left.\pm 1 \mathrm{SD}\right)$ of macroinvertebrates collected in the control (white), one-crayfish (grey) and two-crayfish (black) enclosures. Only graphs for taxa displaying significant effects are depicted: (a) Elmidae, (b) Leuctridae, (c) Brachycentridae, (d) Chironomidae, (e) Hydrobiidae and (f) Polycentropodidae. Crayfish density treatments that significantly differed from each other are denoted with different lowercase letters over the bars ( $a, b)$, and combinations of these letters (ab) indicate a lack of effects in relation to individual groups.

mechanism macroinvertebrates reduce interspecific competition and predation risk (Cooper et al., 1990). Simultaneously, such microdistribution patterns involve a higher variance of abundances to a great degree, thus complicating the detection of effects for particular groups of taxa (Crowl et al., 1997). On the other hand, there is evidence that crayfish species obtain their energy from diverse aquatic or submerged terrestrial resources (Hill et al., 1993; Nyström and Granéli, 1996; Nyström, 2002; Usio and Townsend, 2002; Larson et al., 2017). The absence of macrophytes and detritus spots conditioned by the fast flowing waters, together with the difficulties that crayfish encounter when trying to mechanically extract periphyton (Luttenton et al., 1998), probably led to the high availability of benthic macroinvertebrates at Arroyo del Rincón. We also verified that no cannibalism occurred in the two-crayfish enclosures. Thus, setting aside the distribution patterns of macroinvertebrates, why were no marked effects on them detected? The most plausible explanation is related to the dependance on net balance between predation by crayfish and colonization rate by macroinvertebrates. The latter would arise 
as a process compensating for losses of biota caused by natural or artificial perturbations (Cooper et al., 1990). Although not measured in this study, recolonization by macroinvertebrates after disturbances may be accomplished through four principal pathways: downstream drift, upstream movements, vertical immigration from deep substrates and, in the case of many insects, imago aerial movements for the oviposition of eggs (Williams and Hynes, 1976; Cooper and Barmuta, 1993; Olsen and Townsend, 2005). The zoobenthos replacement is guaranteed in locations where these mechanisms are highly active, at least in terms of taxonomic richness (Reice, 1991). Additionally, it is mostly recognized that at lothic water courses like Arroyo del Rincón, a high drift process would be present (Ilg et al., 2001; Leung et al., 2009), among others. As a consequence, the impact of crayfish may have been counterweighed by the immigration of macroinvertebrates, a process enhanced by mesocosms' permeability to their movement.

\subsection{Effects on particular taxa}

Only the effects of sampling time were detected for some macroinvertebrates, regardless of the presence or absence of crayfish. Therefore, observed patterns presumably fit particular biological cycles. The best example was the gradual decrease in abundance and biomass of leuctrids as the summer progressed. Specifically the nymphs of the determined taxon, Euleuctra geniculata (Stephens, 1836), generally develop over the spring and summer to complete emergence in autumn (Aubert 1963; Puig 1984). Nevertheless, in some Iberian headwaters, emergence can also take place during summer, as a function of local conditions (Ferreras-Romero and AgüeroPelegrín, 1994). Thus, this decrease could be a consequence of the transformation of nymphs into adults. In any case, we could not prove this last because we never considered the capture of aerial imagos of any kind of invertebrate as part of the trials. Midges (Diptera, Chironomidae) generally have prolonged emergence periods throughout spring and autumn, depending on the species (Armitage et al., 2012). Bearing in mind that in our study an undetermined number of species belonging to three subfamilies were cohabiting in the stream, the sudden decline at the beginning of summer was probably related to the emergence of one or several of the majority species. On the other hand, the increase in limnephilids along the trials had much to do with larval recruitment of Apatania sp., yet a great number of tiny larvae were observed during the last sampling surveys. In relation to changes in biomass, the significant gain experienced by riffle beetles (Coleoptera, Elmidae) was probably related to the relative increase in adult numbers, given that they are heavier than larvae. Although riffle beetles are usually present throughout the entire year, according to Elliot (2008) the imaginal stage of the two species present at our experimental stretch, Elmis aenea (Müller, 1806) and Esolus parallelepipedus (Müller, 1806), currently gain importance as the spring progresses. Hydrobiidae, represented by the allochtonous New Zealand mud snail, Potamopyrgus antipodarum (Gray, 1843), was amongst the most important taxa either in abundance or biomass. An explanation for their progressive increase in biomass in the two-crayfish mesocosms is more complex. Aquatic snails are generally considered optimal trophic resources in spite of their small size (Warner, 1997); indeed, a negative impact of freshwater crayfish and crabs on most freshwater snail species has been documented (Abrahamsson, 1966; Perry et al., 1997; Twardochleb et al., 2013; Mills et al., 2016). Such effect could be expected because $P$. antipodarum individuals would easily be captured by crayfish, given their lack of escape abilities. However, the opposite result came of our experiments. Some control exerted by $A$. pallipes through the consumption of other primary consumers could be an option, given that this would result in a reduced competitive pressure on mud snails. Furthermore, the high reproduction rates and an ability to asexually reproduce would have also contributed to mud snail high abundances observed, even monopolizing invertebrate secondary production (Alonso and Castro-Díez, 2008). To a great extent, the absence of impacts on particular taxa would be influenced by crayfish foraging behaviour. These crustaceans usually probe the substrate continuously with their antennae and walking legs in a random pattern (Holdich, 2002). This habit does not involve such an active and selective searching process as long as it is determined by stochastic predator-prey encounter rates (Cooper et al., 1985; Peckarsky, 1996). That is, no special attention would be paid by crayfish to a particular taxa, resulting in a generalised weak foraging pressure on each group. At this point, vulnerability of potential prey becomes a major factor overlapping with the aforementioned foraging tactics. Vulnerability of macroinvertebrates to $A$. pallipes depends on passive (microhabitat, body size) and active features (motility or evasive capabilities). Many of these potential prey species exhibit diverse and often complex predator-avoidance behaviours, which may evolve over time (Sih et al., 2010). For instance, macroinvertebrates with burrowing habits or living in streambed interstices as aquatic worms, caenids or chironomids are less likely to be captured (Nyström and Granéli, 1996; Twardochleb et al., 2013), as well as very small organisms. Riffle beetles are infrequently found in predator guts presumably due to their poor palatability (Elliot, 2008). Moreover, highly motile taxa such fast crawlers or good swimmers, i.e. most mayflies or amphipods, increase their evasiveness in relation to slowmoving macroinvertebrates (Lodge et al., 1994; Nyström and Granéli, 1996; Parkyn et al., 1997; Mathers et al., 2016). A pioneer study conducted by Abrahamsson (1966) confirmed the inability of larger crayfish to catch fast-moving invertebrate prey. In that case, the population recovery of aquatic snails and leeches - both slow-moving and easily-handled organisms - after a crayfish plague outbreak was recorded.

In the end, a theoretical impact of white-clawed crayfish on the structure of benthic macroinvertebrate assemblages could not be demonstrated in the planned operating conditions. The main community drivers - richness, abundance, biomass and diversity - did not show significant short-term changes when A. pallipes was present. This was somewhat unexpected given that previous studies had detailed direct and indirect effects of various crayfish species on aquatic macroinvertebrates (Hill et al., 1993; Matthews et al., 1993; Momot, 1995; Parkyn et al., 1997). However, the precise balance between predation, herbivory and detritivory may be context-dependent (Larson et al., 2017). And in our case, a mixed efficiency of natural recolonization and resistance by macroinvertebrates less vulnerable to crayfish could be behind this lack of net effects, 
as previous information suggests. Perhaps an increase in the crayfish densities employed in the mesocosmos would have produced clearer results, an issue to consider for future research in this topic. On the other hand, variations in density and/or biomass of particular taxa occurred but only associated with the passage of time, and thus biological cycles of organisms must be responsible for these significant differences (Reynoldson and Wright, 2000). The reasons for the few interactions detected between crayfish density and sampling time could not be determined with any certainty. The above information should be taken into account when proposing reintroduction actions for $A$. pallipes in similar calcareous headwaters in order to maintain viable, wild populations. But we urge caution as this was a short-term experiment, and the enclosure method employed does not stop representing semicontrolled conditions. In this sense additional research characterizing crayfish feeding ecology and spatial/temporal habitat use by macroinvertebrates needs to be performed from different approaches - long-term periods, higher densities of crayfish, inhabited vs non-inhabited streams, etc - to provide further understanding of the effects of crayfish on stream macrobenthic communities.

Acknowledgements. This work was financially supported by Project SIA 03-218-RN-32, promoted by Castile-La Mancha Regional Ministry of Agriculture. The main author was supported with a grant from the National Institute for Agricultural and Food Research and Technology. Development of field trials was approved by the staff of the Rincón de Uña fish hatchery. We thank the two anonymous reviewers for their constructive editorial comments. We also wish to thank Orencio Sánchez for his technical help in carrying out the field trials.

\section{References}

Abrahamsson SAA. 1966. Dynamics of an isolated population of the crayfish Astacus astacus Linné. Oikos 17: 96-107.

Alonso F. 2004. Dinámica de las poblaciones del cangrejo de río Austropotamobius italicus (Faxon, 1914) en el Sistema Ibérico: aplicaciones a la recuperación de la especie. Ph.D. thesis, Universidad Politécnica de Madrid, Spain.

Alonso F. 2011. Austropotamobius italicus (Faxon, 1914). In Verdú JR, Numa C, Galante E, eds. Atlas y Libro Rojo de los Invertebrados amenazados de España (Especies Vulnerables), Dirección General de Medio Natural y Política Forestal, Ministerio de Medio Ambiente, Madrid: Medio Rural y Marino, 651-672.

Alonso F, Temiño C, Diéguez-Uribeondo J. 2000. Status of the whiteclawed crayfish, Austropotamobius pallipes (Lereboullet, 1858) in Spain: legislation and conservation. Knowl Manag Aquat Ecosyst 356: 31-54.

Alonso A, Castro-Díez P. 2008. What explains the invading success of the aquatic mud snail Potamopyrgus antipodarum (Hydrobiidae, Mollusca)? Hydrobiologia 614: 107-116.

Arce JA, Alonso F. 2011. Factors related to the presence of the Austropotamobius pallipes (Lereboullet, 1858) species complex in calcareous mountain rivers in central Spain. Knowl Manag Aquat Ecosyst 401: 25.

Armitage PDL, Pinder C, Cranston P. 2012. The Chironomidae: biology and ecology of non-biting midges, London: SpringerVerlag/Sci-Tech/Trade, $572 \mathrm{pp}$.
Aubert J. 1963. Les Plécoptères de la Péninsule Ibérique. Eos 39: 23-107.

Benvenuto C, Gherardi F, Ilhéu M. 2008. Microhabitat use by the white-clawed crayfish in a Tuscan stream. J Nat Hist 42: 21-33.

Brown PB, Tazik P, Hooe ML, Blythe WG. 1990. Consumption and apparent dry matter digestibility of aquatic macrophytes by male and female crayfish (Orconectes virilis). Aquaculture 89: $55-64$.

Burgazzi G, Guareschi S, Laini A. 2018. The role of small-scale spatial location on macroinvertebrate community in an intermittent stream. Limnetica 37: 319-340.

Camargo J. 2019. Positive responses of benthic macroinvertebrates to spatial and temporal reductions in water pollution downstream from a trout farm outlet. Knowl Manag Aquat Ecosyst 420: 16.

Casas JJ. 1996. Environmental patchiness and processing of maple litter in a backwater of a mountain stream: riffle area vs debris dams. Fundam Appl Limnol 136: 489-508.

Chiesa S, Scalici M, Negrini R, Gibertini G, Nonnis Marzano F. 2011. Finescale genetic structure, phylogeny and systematics of threatened crayfish species complex. Mol Phylogenet Evol 61: $1-11$.

Cole MB, Russell KR, Mabee TJ. 2003. Relation of headwater macroinvertebrate communities to in-stream and adjacent stand characteristics in managed second-growth forests of the Oregon Coast Range mountains. Can J Fish Aquat Sci 33: 1433-1443.

Cooper SD, Barmuta LA. 1993. Field experiments in biomonitoring. In Rosemberg DM, Resh VH, eds. Freshwater biomonitoring and benthic macroinvertebrates. London, UK: Chapman \& Hall, 399-441.

Cooper SD, Smith DW, Bence R. 1985. Prey selection by freshwater predators with different foraging strategies. Can J Fish Aquat Sci 42: $1720-1732$.

Cooper SD, Walde SG, Peckarsky BL. 1990. Prey exchange rates and the impact of predators on prey populations in streams. Ecology 71 : $1503-1514$

Crowl TA, Townsend CR, Bouwes N, Thomas H. 1997. Scales and causes of patchiness in stream invertebrate assemblages: top-down predator effects? J N Am Benthol Soc 16: 277-285.

Davic RD. 2003. Linking keystone species and functional groups: A new operational definition of the keystone species concept. Conserv Ecol 7: r11.

Diéguez-Uribeondo J. 2006. Pathogens, parasites and ectocommensals. In Souty-Grosset C, Holdich DM, Noël PY, Reynolds JD, Haffner P, eds. Atlas of crayfish in Europe, Paris: Muséum National d'Histoire Naturelle, pp. 131-149.

Elliot JM. 1977. Some methods for the statistical analysis of samples of benthic invertebrates, 2nd edn. Freshwater Biological Association. Ambleside, UK: Scientific Publication, 25, 159 pp.

Elliot JM. 2008. The ecology of riffle beetles. Freshw Rev 1: 189-203.

Ferreras-Romero M, Agüero-Pelegrín M. 1994. Nymphal growth and development of Euleuctra geniculata Stephens, 1835 (Plecoptera: Leuctridae) in the Sierra Morena mountains, Southern Spain. Limnetica 10: 9-13.

Flecker AS, Allan JD. 1984. The importance of predation, substrate and spatial refugia in determining lotic insect distributions. Oecologia 64: 306-313.

Friedrich G, Chapman D, Beim A. 1992. The use of biological material. In: Chapman D, ed. Water quality assessments, London: WHO-UNESCO, 171-238.

Füreder L. 2006. Indigenous crayfish habitat and threats. In SoutyGrosset C, Holdich DM, Noël PY, Reynolds JD, Haffner P, eds. Atlas of crayfish in Europe, Paris: Muséum National d'Histoire Naturelle, 25-47. 
García-Arberas L, Rallo A, Antón A. 2009. The future of the indigenous freshwater crayfish Austropotamobius italicus in Basque Country streams: Is it possible to survive being an inconvenient species? Knowl Manag Aquat Ecosyst 19: 394-395.

Geiger W, Alcorlo P, Baltanás A, Montes C. 2005. Impact of an introduced Crustacean on the trophic webs of Mediterranean wetlands. Biol Invasions 7: 49-73.

Haddaway NR, Wilcox RH, Heptonstall RE, Griffiths HM, Mortimer RJ, Christmas M, Dunn AM. 2012. Predatory functional response and prey choice identify predation differences between native/ invasive and parasitised/unparasitised crayfish. PLOS ONE 7: e32229.

Hansen GJA, Hein CL, Roth BM, Vander Zanden MJ, Gaeta JW, Latzka AW, Carpenter SR. 2013. Food web consequences of longterm invasive crayfish control. Can J Fish Aquat Sci 70: $1109-1122$

Hill AM, Sinars DM, Lodge DM. 1993. Invasion of an occupied niche by the crayfish Orconectes rusticus: potential importance of growth and mortality. Oecologia 94: 303-306.

Holdich DM. 2002. Background and functional morphology. In: Holdich DM, ed. Biology of Freshwater Crayfish. UK: Blackwell Science Ltd, 3-29.

Holdich DM, Haffner P, Noël PY. 2006. Species files. In SoutyGrosset C, Holdich DM, Noël PY, ReynoldsJD, Haffner P, eds. Atlas of crayfish in Europe. Paris: Muséum National d'Histoire Naturelle, pp.49-129.

Ilg C, Castella E, Lods-Crozet B, Marmonier P. 2001. Invertebrate drift and physico-chemical variables in the tributaries of the Mutt, a Swiss glacial stream. Fundam Appl Limnol 151: 335-352.

Ilhéu M, Bernardo JM. 1993. Experimental evaluation of food preferences of red swamp crayfish, Procambarus clarkii: vegetal versus animal. Freshw Crayfish 9: 359-364.

Ilhéu M, Bernardo JM. 1995. Trophic ecology of red swamp crayfish Procambarus clarkii (Girard): preferences and digestibility of plant foods. Freshw Crayfish 10: 132-139.

Leung ES, Rosenfeld JS, Bernhardt JR. 2009. Habitat effects on invertebrate drift in a small trout stream: implications for prey availability to drift-feeding fish. Hydrobiologia 623: 113-125.

Larson ER, Twardochleb LA, Olden JD. 2017. Comparison of trophic function between the globally invasive crayfishes Pacifastacus leniusculus and Procambarus clarkii. Limnology 18: 275-286.

Lodge DM, Kershner MW, Aloi JE, Covich A. 1994. Effects of an omnivorous crayfish (Orconectes rusticus) on a freshwater littoral food web. Ecology 75: 1265-1281.

Luttenton MR, Horgan MJ, Lodge DM. 1998. Effects of three Orconectes crayfishes on epilithic microalgae: a laboratory experiment. Crustaceana 71: 845-855.

Mathers KL, Chadd RP, Dumbar MJ, Extence MA, Reeds J, Rice SP, Wood PJ. 2016. The long-term effects of invasive signal crayfish (Pacifastacus leniusculus) on instream macroinvertebrate communities. Sci Total Environ 556: 207-218.

Mathews P. 2010. Sample size calculations: Practical methods for engineers and scientists. Mathews Malnar and Bailey, Inc., 338 p.

Matthews M, Reynolds JD, Keatinge MJ. 1993. Macrophyte reduction and benthic community alteration by the crayfish Austropotamobius pallipes (Lereboullet). Freshw Crayfish 9: 289-299.

Mills CD, Clark PF, Morrit D. 2016. Flexible prey handling, preference and a novel capture technique in invasive, subadult Chinese mitten crabs. Hydrobiologia 773: 135-147.

Momot WT. 1995. Redefining the role of crayfish in aquatic ecosystems. Rev Fish Sci 3: 33-63.
Nijboer NC, Verdonschot PFM. 2004. Rare and common macroinvertebrates: Definition of distribution classes and their boundaries. Fundam Appl Limnol 161: 45-64.

Nyström P. 2002. Ecology. In: Holdich DM, ed. Biology of freshwater crayfish, UK: Blackwell Science Ltd, 192-235.

Nyström P, Granélli W. 1996. The effect of food availability on survival, growth, activity and the number of mature females in crayfish populations. Freshw Crayfish 11: 170-181.

Olsen DA, Townsend CR. 2005. Flood effects on invertebrates, sediments and particulate organic matter in the hyporheic zone of a gravel-bed stream. Freshw Biol 50: 839-853.

Olsson K, Nyström P, Stenroth P, Nilsson E, Svensson M, Granéli W. 2008. The influence of food quality and availability on trophic position, carbon signature, and growth rate of an omnivorous crayfish. Can J Fish Aquat Sci 65: 2293-2304.

Parkyn SM, Rabeni CF, Collier KJ. 1997. Effects of crayfish (Paranephrops planifrons: Parastacidae) on in-stream processes and benthic faunas: a density manipulation experiment. $N Z J M a r$ Freshw Res 31: 685-692.

Peckarsky BL. 1996. Predator-prey interactions. In Hauer FR, Lamberti GA, eds. Methods in stream ecology. London, UK: Academic Press, pp.431-451.

Peh KSH, Lewis SL, Lloyd J. 2011. Mechanisms of monodominance in diverse tropical tree-dominated systems. J Ecol 99: 891-898.

Perry WR, Lodge DM, Lamberti GA. 1997. Impact of crayfish predation on exotic zebra mussels and native invertebrates in a lake-outlet stream. Can J Fish Aquat Sci 54: 120-125.

Peterson BJ, Wollheim WM, Mulholland PJ, Webster JR, Meyer JL, Tank JL, Marti E, Bowden WB, Valett HM, Hershey AE, McDowell WH, Dodds WK, Hamilton SK, Gregory S, Morrall DD. 2001. Control of nitrogen export from watersheds by headwater streams. Science 292: 86-90.

Puig MA. 1984. Distribution and ecology of the stoneflies (Plecoptera) in Catalonian Rivers (NE-Spain). Ann Limnol 20: $75-80$.

Reice SR. 1991. Effects of detritus loading and fish predation on leafpack breakdown and benthic macroinvertebrates in a woodland stream. J N Am Benthol Soc 10: 42-56.

Resh VH, Jackson JK. 1993. Rapid assessment approaches to biomonitoring using benthic macroinvertebrates. In Rosemberg DM, Resh VH, eds. Freshwater biomonitoring and benthic macroinvertebrates. London, UK: Chapman and Hall, 195-233.

Reynolds JD, Souty-Grosset C, Richardson A. 2013. Ecological roles of crayfish in freshwater and terrestrial habitats. Freshw Crayfish 19: $197-218$.

Reynoldson TB, Wright JF. 2000. The reference condition: problems and solutions. In Wright JF, Sutcliffe DV, Furse MT, eds. Assessing the biological quality of fresh waters: RIVPACS and others techniques. Ambleside, Cumbria, UK: Freshwater Biological Association, pp. 293-303.

Rodrígues-Captulo A, Muñoz I, Bonada N, Gaudes A, Tomanova S. 2009. La biota de los ríos. In Elosegi A, Sabater S, eds. Conceptos y técnicas en ecología fluvial. Bilbao: Fundación BBVA, $253-270$

Rodríguez CF, Bécares E, Fernández-Aláez M, Fernández-Aláez C. 2005. Loss of diversity and degradation of wetlands as a result of introducing exotic crayfish. Biol Invasions 7: 75-85.

Rosewarne PJ, Mortimer RJG, Newton RJ, Grocock G, Wing CD, Dunn AM. 2016. Feeding behaviour, predatory functional responses and trophic interactions of the invasive Chinese mitten crab (Eriocheir sinensis) and signal crayfish (Pacifastacus leniusculus). Freshw Biol 61: 426-443. 
Sih A, Bolnick DI, Luttbeg B, Borrock JL, Peacor SD, Pintor LM, Preisser E, Rehage JS, Vonesh JR. 2010. Predator-prey naïveté, antipredator behavior, and the ecology of predator invasions. Oikos 119: 610-621.

Sokal RR, Rohlf FJ. 1995. Biometry: the principles and practice of statistics in biological research, 3rd ed. New York: W.H. Freeman, $887 \mathrm{pp}$.

Taylor NG, Dunn AM. 2018. Predatory impacts of alien decapod Crustacea are predicted by functional responses and explained by differences in metabolic rate. Biol Invasions 20: 2821-2837.

Townsend CR, Hildrew AG. 1994. Species traits in relation to a habitat template for river systems. Freshw Biol 31: 265-275.

Twardochleb LA, Olden JD, Larson ER. 2013. A global metaanalysis of the ecological impacts of nonnative crayfish. Freshw Sci 32: $1367-1382$.

Usio N, Townsend CR. 2002. Functional significance of crayfish in stream food webs: roles of omnivory substrate heterogeneity and sex. Oikos 98: 512-522.

Vannote RL, Minshall GW, Cummins KW, Sedell JR, Cushing CE. 1980. The River Continuum Concept. Can J Fish Aquat Sci 37: $130-137$.
Wallace JB, Eggert SL, Meyer JL, Webster JR. 1997. Multiple trophic levels of a forest stream linked to terrestrial litter inputs. Science 277: 102-104.

Warner GF. 1995. Choice and consumption of aquatic weeds by signal crayfish (Pacifastacus leniusculus). Freshw Crayfish 8: 360-363.

Warner GF. 1997. Factors affecting the selection of pond snail prey by signal crayfish. Freshw Crayfish 11: 194-202.

Wendler F, Biss R, Chucholl C. 2015. Population ecology of endangered white-clawed crayfish (Austropotamobius pallipes $\mathrm{s}$. str.) in a small rhithral river in Germany. Knowl Manag Aquat Ecosyst 416: 24.

Whitledge GW, Rabeni CF. 1997. Energy sources and ecological role of crayfishes in an Ozark stream: insights from stable isotopes and gut analysis. Can J Fish Aquat Sci 54: 2555-2563.

Williams DD, Feltmate BW. 1992. Aquatic insects. CAB International. UK: Wallingford

Williams DD, Hynes HBN. 1976. The recolonization mechanisms of stream benthos. Oikos 27: 265-272.

Woodiwiss FS. 1978. Biological water assessment methods. UK: Severn-Trent River Authorities, $53 \mathrm{p}$.

Cite this article as: Arce JA, Alonso F, Camacho A, Rico E. 2019. Do native white-clawed crayfish impact macroinvertebrate assemblages in Mediterranean limestone headwaters? Knowl. Manag. Aquat. Ecosyst., 420, 33. 
J.A. Arce et al.: Knowl. Manag. Aquat. Ecosyst. 2019, 420, 33

Appendix A. List of macroinvertebrates found in the mesocosmos sampled at Arroyo del Rincón.

\begin{tabular}{|c|c|c|}
\hline Class/order & Family & Subfamily/gender/species \\
\hline Turbellaria & Planariidae & Polycelis sp. \\
\hline Hirudinea & $\begin{array}{l}\text { Erpobdellidae } \\
\text { Glossiphoniidae }\end{array}$ & $\begin{array}{l}\text { Dina lineata (Müller, 1774) } \\
\text { Glossiphonia complanata (Linnaeus, 1758) }\end{array}$ \\
\hline \multicolumn{3}{|l|}{ Oligochaeta } \\
\hline Mollusca & $\begin{array}{l}\text { Ancylidae } \\
\text { Hydrobiidae } \\
\text { Lymnaeidae } \\
\text { Planorbiidae }\end{array}$ & $\begin{array}{l}\text { Ancylus fluviatilis (Müller, 1774) } \\
\text { Potamopyrgus antypodarum (Gray, 1843) } \\
\text { Radix peregra (Müller, 1774) }\end{array}$ \\
\hline $\begin{array}{l}\text { Crustacea } \\
\text { Hydracarina }\end{array}$ & Gammaridae & Gammarus ibericus (Margalef, 1951) \\
\hline Ephemeroptera & $\begin{array}{l}\text { Baetidae } \\
\text { Ephemerellidae } \\
\text { Heptageniidae } \\
\text { Leptophlebiidae }\end{array}$ & $\begin{array}{l}\text { Baetis rhodani (Pictet, 1845) } \\
\text { Serratella ignita (Poda, 1761) } \\
\text { Ecdyonurus sp., Rhithrogena sp. } \\
\text { Habroleptoides sp. }\end{array}$ \\
\hline Plecoptera & $\begin{array}{l}\text { Nemouridae } \\
\text { Leuctridae } \\
\text { Perlidae } \\
\text { Perlodidae }\end{array}$ & $\begin{array}{l}\text { Protonemura } \mathrm{sp} . \\
\text { Euleuctra geniculata (Stephens, 1836) } \\
\text { Perla } \mathrm{sp.} \\
\text { Isoperla } \mathrm{sp} .\end{array}$ \\
\hline \multirow[t]{3}{*}{ Coleoptera } & Elmidae & $\begin{array}{l}\text { Elmis aenea (Müller, 1806), Esolus paralellepipedus (Müller, 1806), } \\
\text { Esolus angustatus (Müller, 1821), }\end{array}$ \\
\hline & $\begin{array}{l}\text { Haliplidae } \\
\text { Hydrophilidae }\end{array}$ & Haliplus sp. \\
\hline & Scirtidae & Elodes sp. \\
\hline \multirow[t]{5}{*}{ Trichoptera } & $\begin{array}{l}\text { Brachycentridae } \\
\text { Glossosomatidae } \\
\text { Hydropsychidae } \\
\text { Hydroptilidae }\end{array}$ & $\begin{array}{l}\text { Micrasema sp. } \\
\text { Agapetus sp. } \\
\text { Hydropsyche } \mathrm{sp} .\end{array}$ \\
\hline & Limnephilidae & Apatania sp., Subfam Limnephilinae \\
\hline & Polycentropodidae & Plectrocnemia sp. \\
\hline & Rhyacophilidae & Rhyacophila dorsalis (Curtis, 1834) \\
\hline & Sericostomatidae & Sericostoma sp. \\
\hline \multirow[t]{7}{*}{ Diptera } & Anthomyidae & \\
\hline & $\begin{array}{l}\text { Ceratopogonidae } \\
\text { Chironomidae }\end{array}$ & Subfam. Chironominae, Orthocladinae y Tanypodinae \\
\hline & Dixidae & \\
\hline & Empididae & \\
\hline & Psychodidae & \\
\hline & Simuliidae & \\
\hline & Stratiomyidae & \\
\hline
\end{tabular}

